\title{
Evaluation and Reliability of the Organic Certification System: Perceptions by Farmers in Latin America
}

\author{
Friederike Albersmeier,* Holger Schulze and Achim Spiller \\ University of Goettingen, Department of Agricultural Economics and Rural Development, Germany
}

\begin{abstract}
In recent years, organic agriculture has developed rapidly, and organic certification systems are now used worldwide. However, if these standards are unable to meet their promises, their reliability will be called into question and trust in organic products will fade. As major suppliers of organic food to the European market, it is crucial for Latin American farmers to show their customers that the standards they have implemented are actually delivering what they promise. Considering the manifold resources that are being poured into these systems, it seems reasonable to critically review their reliability. A central indicator for the reliability of the system is the overall evaluation of organic certification. Therefore, it is the objective to analyse the relationship of both constructs. Findings show that most farmers are satisfied with the organic certification system and believe in its reliability; however, they fear the costs of bureaucracy and documentation. Copyright (c) 2009 John Wiley \& Sons, Ltd and ERP Environment.
\end{abstract}

Received 19 November 2008; revised 30 April 2009; accepted 7 May 2009

Keywords: quality assurance systems (QASs); organic certification; farming; Latin America; structural equation modelling

\section{Introduction}

N RECENT YEARS, ORGANIC AGRICULTURE HAS DEVELOPED RAPIDLY, AND ORGANIC CERTIFICATION STANDARDS ARE NOW applied in around I20 countries (Willer and Yussefi, 2006). The international expansion of organic standards partially reflects the import activities of northern countries since demand remains concentrated in Europe and North America. Despite the impressive growth in domestic production, these markets suffer an immense undersupply and have to import large volumes of organic products (Barrett et al., 2002). The increasing trade activities lead to discussions about the danger of mislabelling.

The question of organic mislabelling is embedded in the general debate about the ability of traditional governmental regulators to prevent fraud in the food industry. Various scandals and crises undermine consumers' confidence. Hence, consumers are demanding more information about production and the guarantee of food safety and quality. As a result, many European countries have launched initiatives to implement standards, as has the private sector (Vermeulen, 2008). Therefore, a multiplicity of certification systems has been established (Jahn et al., 2005). The EU certification scheme for organic farming is one of the most prominent ones.

* Correspondence to: Friederike Albersmeier, M.Sc., University of Goettingen, Department of Agricultural Economics and Rural Development, Platz der Goettinger Sieben 5, 37073 Goettingen, Germany. E-mail: falbers@uni-goettingen.de 
However, these systems greatly depend on the confidence that they are keeping their promises to assure food quality and safety. Unfortunately, the various scandals have shown that quality assurance systems (QAS) are generally susceptible to opportunistic behaviour. In 2000, about 10\% of organic corn sold in Germany came from conventional agriculture (Jahn et al., 2005). Other examples of imperfect monitoring can be found in the work of Anania and Nisticò (2004), Neuendorff and Fischer (2007) and McCluskey (2000).

In Europe, Council Regulation (EEC) 2092/9I defines the production as well as the inspection of organic products. The revised version - (EEC) 834/2007 - proposes 'to improve and reinforce the Community's organic farming standards and import and inspection requirements'. This also applies to exporting countries (Barrett et al., 2002), such as Latin America, which today is an important supplier of organic food to the European market. Thus, it is crucial for these countries to show their customers that the standards being implemented are actually working. This is of tremendous importance since they took the chance to solve their environmental and social problems by introducing organic farming (Bonapace, 200I). Hence, organic farming greatly contributes to sustainable development by addressing not only the ecological dimensions of sustainability (Pawłowski, 2008).

Considering this background, it seems reasonable to critically review the reliability of organic certification. Today, only very few papers deal with this issue (Jahn et al., 2005; Anders et al., 2007; Amstel et al., 2007). To our knowledge, no such study exists for the developing countries confronted with European organic certification. The following paper contributes to this discussion by evaluating the reliability of organic certification in Latin America. For this purpose the paper provides information on the institutional framework of QAS and gives a brief insight into organic farming in Latin America. Previous research in this field is presented in a literature review. The fourth section outlines the research framework - the applied model, data collection, the measures used and the statistical approach. Then, the measurement model is tested, and results are described. Finally, the findings are discussed, and conclusions are drawn.

\section{The Implementation of Organic Certification}

\section{Institutional Framework}

Certification is defined as 'the (voluntary) assessment and approval by an (accredited) party on an (accredited) standard' (Meuwissen et al., 2003). Its starting point is the flow of goods between farmers, processors, retailers and consumers. Generally, a neutral certifier (third-party certification) controls the compliance of the farmer through criteria regarding certification standards. In the case of a positive event, an (organic) certificate is issued. By guaranteeing these inspection processes at all stages of the supply chain, the certificate can serve as a reliable quality signal along the supply chain.

Today, especially in Europe, large parts of the agribusiness are certified according to a variety of schemes. These QASs can be differentiated according to various characteristics (see Theuvsen and Spiller, 2007). Most standards are developed by private standardization organizations such as GlobalGAP, the International Food Standard (IFS) or British Retail Consortium (BRC) and private certification bodies carrying out the inspections. IFS and GlobalGAP are widely used certification schemes - currently, more than 4935 food producers worldwide are certified according to the IFS, and GlobalGAP has issued more than $5^{\mathrm{I}} 000$ certificates in the fruit and vegetable sector in more than 60 countries. In addition, the BRC Standard is the counterpart of IFS for food producers supplying retail branded goods to the United Kingdom (Schulze et al., 2008). These schemes were introduced mainly by food retailers and focus on the respective product and its processing. Several standards also address environmental and social aspects of the production process (such as child labour or waste disposal) (Beske et al., 2008).

In organic certification, in contrast, the government is the standard-setting body in most developed countries (Martinez and Bañados, 2004). The EU was the first to work on norms for organic agriculture. It created and approved Council Regulation (EEC) 2092/9I, a uniform standard for organic farming, labelling and certification (revised version 834/2007). Another important achievement was the US Organic Food Production Act, which went into force in 2000. Unlike most of the above-mentioned schemes, organic certification is a process covering the whole supply chain: agricultural operations as well as processors and traders are inspected. However, organic 
certification is principally a certification of major production processes (except storage and transport) and not of the actual product (Bonapace, 200I).

Despite the official status of the QAS, information asymmetries and the fast growing organic market raise questions of mislabelling and opportunism. Fraud can be ascribed to the 'process quality' of organic production since it cannot be detected in the final product. Consequently, a high degree of information asymmetry normally occurs in markets with such credence attributes (McCluskey, 2000). Hence, the institutional framework of certification is a crucial factor for the organic market. When consumers' trust in certification falls below a certain threshold, consumer welfare and demand decrease, which can result in a market collapse (Giannakas, 200I).

\section{Organic Certification in Latin America}

Latin America has experienced extraordinary growth rates in organic production in recent years. Starting from a comparatively low production level, these countries now contribute around $20 \%$ of the world's organic land and have the greatest total number of organic farms (Yussefi, 2006). Although even the local market for organic products has been growing, export still predominates. The European Union and the United States are the main organic export markets; thus, their regulations are essential for international trade (see Barrett et al., 2002).

Costa Rica and Brazil hold unique positions among the Latin American countries: Costa Rica possesses Third Country Status, which means that the national regulations on organic production are accepted as equivalent with those in Europe (Willer and Yussefi, 2006). Brazil is a major exporter of organic products to Europe. Around 90\% of its organic foodstuffs are produced for export markets. These considerations led us to choose these countries for our analysis.

Costa Rica has proceeded very quickly in implementing institutions to handle organic farming. Governmental support started with the creation of the National Program of Organic Agriculture in I994. In 2006, Costa Rica's National Strategy for the Promotion of Organic Production went into force. Today, organic farming accounts for just $0.33 \%$ of the country's total agricultural farm land. Informal estimates calculate the existence of around 4000 organic producers in the country (Willer and Yussefi, 2006).

In 2005 , Brazil was the sixth largest grower of organic products in the world with respect to organic farm land. Around $0.3 \%$ ( $887637 \mathrm{ha}$ ) of the total agricultural area is organically managed (Willer and Jussefi, 2006). In I999, the National Department of Agriculture started to show concern about regulation of the organic sector. Four years later, Brazil's Organic Law No. I0,83I was passed, which specifies the description and objectives of the organic production system.

\section{Literature Review: Evaluation and Reliability of QAS}

While some studies have already dealt with consumer perceptions and trust in organic food (see Botanaki et al., 2005; Batte et al., 2007), research with an explicit focus on the attitudes of the farmers towards QAS and organic certification is rare (Fitzgerald et al., I999; Böcker et al., 2003; Jahn and Spiller, 2005). However, it is important to know about farmers' acceptance and motivations, because a scheme that is considered a bureaucratic burden will be susceptible to fraud. Thus, besides other supply chain members, farmers have a direct influence on the success of the implemented QAS. In the following we review the existing literature on evaluation and reliability of QASs.

Literature dealing with the evaluation of QASs indicates that the user associates a number of benefits but also disadvantages with such schemes (Schulze et al., 2008). In their study on ISO implementation in industrial and service firms, Singels et al. (200I) generally differentiate between internal and external benefits. While internal benefits refer to the realization of a continuous improvement process seeking to advance a company's activities and firm structure, external benefits evolve from the relationship between the company and its stakeholders.

In the food business, higher transparency, traceability and positive effects on performance and cost structures are identified as strengths (Jatib, 2003). QAS implementation has reduced incidences of product failures, recalls, customer complaints and warranty claims. The main external advantages were the attraction and maintenance of 
customers as well as satisfaction with sales and market share (Fouayzi et al., 2006). Larger companies in particular expect an effective savings potential; smaller firms, in contrast, hope to gain a competitive advantage (Caswell et al., I998). On the other hand, one of the most common complaints is that standards offer few benefits for day-to-day operations but result in a huge bureaucratic workload (Gawron and Theuvsen, 2006). Many users feel incapacitated by the strict regulations imposed by QAS. Costs are associated mainly with training staff to establish and maintain the system, record keeping and the implementation of monitoring procedures, laboratory work and assumed process modifications (Fouayzi et al., 2006).

In developing countries, Kleinwechter and Grethe (2006) identify access to information and lack of knowledge as major difficulties for farmers when implementing GlobalGAP. Furthermore, the established infrastructure does not always allow for the changes needed to meet the requirements (Martinez and Bañados, 2004). Besides, the costs of compliance can create a substantial economic burden and, therefore, represent the most relevant stumbling block to adoption (Barrett et al., 2002; Getz and Shreck, 2006). In addition, benefits of organic certification are varied. Firstly, organic certification provides access to markets in developed countries with high and stable prices (Getz and Shreck, 2006). In this way, 'new partnerships within the whole value chain' are developed and 'selfconfidence and autonomy of the farmers' are emphasized (Kilcher, 2007). Moreover, organic certification facilitates the diffusion of organic practices and, consequently, their sustainable outcome (Vermeulen and Ras, 2006). However, Getz and Shreck (2006) analyse these positive effects and question the connectivity 'between expectation raised by the label and the "lived experience" of production'.

Besides the farmer's satisfaction with organic certification, the expertise of the auditor exerts an influence on the reliability of the certification system (Jahn et al., 2005). Anders et al. (2007) analyse the objectivity of GlobalGAP's certifiers. They conclude that inspectors 'may be affected by the competitive structure of the certification market'. However, despite a broad literature analysing the performance of QASs in international business and, to a lesser extent, in agribusiness, no research has been conducted analysing the credibility of QASs in the agrifood sector.

\section{Research Framework}

\section{Research Model and Hypotheses}

There are two basic starting points for a reliability analysis of organic certification - objective and subjective measurement. Whereas objective measurement is based on data from detected cases of fraud or pesticide residue monitoring, subjective measurement analyses the attitudes of stakeholders (such as farmers, processors, exporters or certifiers) through empirical research. With regard to objective measurement, no suitable publicly available statistical data exists that could be used for a reliability analysis. Therefore, it seems necessary to focus on subjective measurement. In this study we exclusively focus on the producers' perspective, since they are the first in the value chain and directly deal with the requirements. Thus, the aim of the study is to analyse how farmers perceive the reliability of the organic certification system and how the overall evaluation influences the reliability (see Figure I).

The first construct, 'overall evaluation' of the organic certification system, is conceptualized as the reaction of individuals toward the use of the organic certification system. Some authors (see Maes et al., 2005) have suggested that a general attitude towards the use of a certification scheme should be measured in terms of how satisfied users are with the scheme. Satisfaction is described as 'an evaluation of an emotion' (Hunt, I977), indicating that it reflects the degree to which a person believes that the possession and/or use of a system evokes positive feelings (Rust and Oliver, I994). The construct was operationalized by asking respondents about their satisfaction with organic certification.

The measurement of 'perceived usefulness' of certification systems has already been applied in previous research (Schulze et al., 2008). Various studies indicated that, for most companies, certification entails internal benefits (e.g. operational benefits and increasing farm income) and external benefits (e.g. market access and a strengthened relationship with buyers). However, the extent to which this is true depends on demographic and structural varieties (Schulze et al., 2008). In this study, we define the 'perceived usefulness' construct as performance 


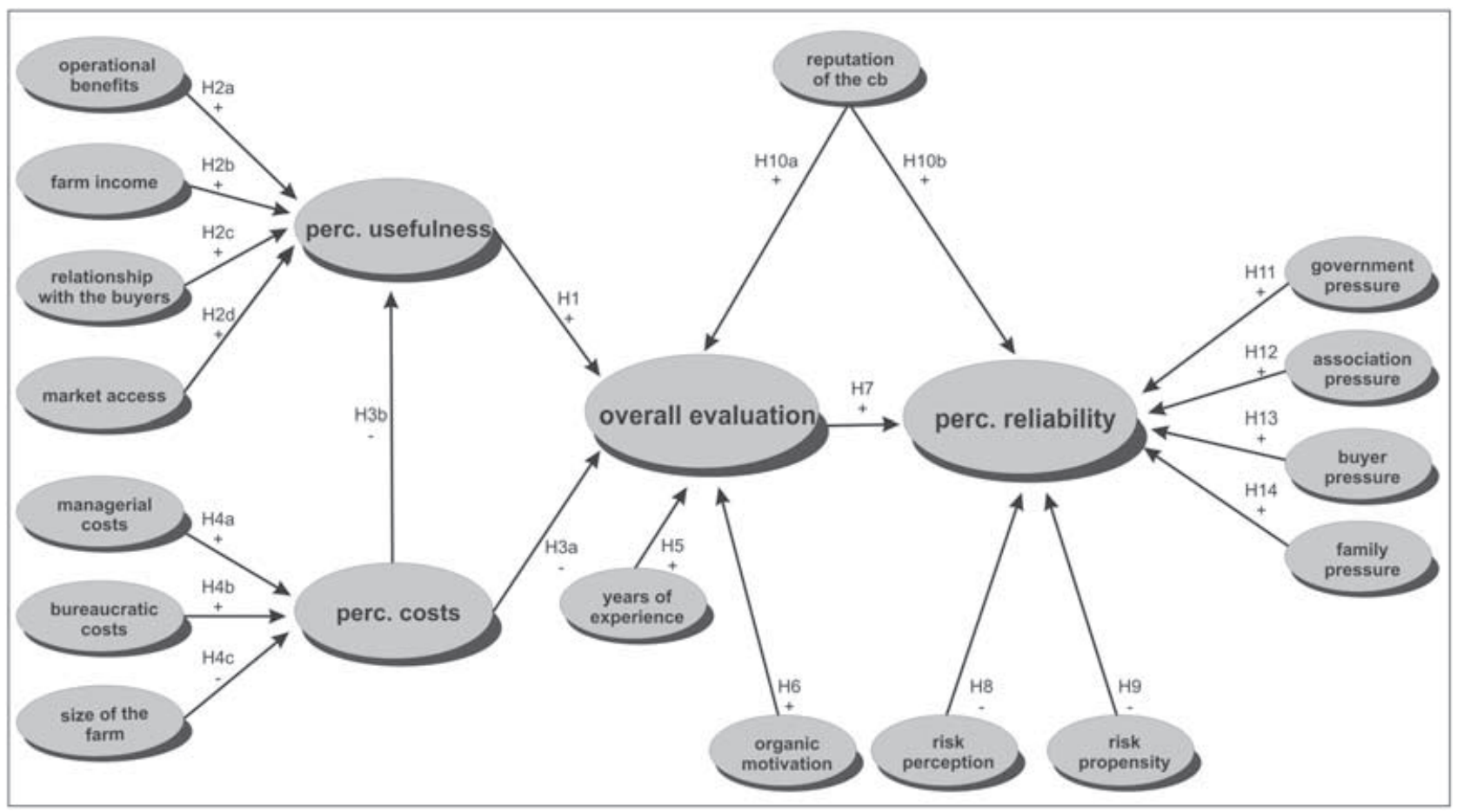

Figure 1. Research model

improvements that farmers perceive through implementing organic certification. We formulate the hypothesis that the greater the perceived usefulness is, the more favourable the overall evaluation of organic certification will be (HI). In addition, we add two subconstructs in order to explain internal benefits ('perceived operational benefits' (H2a) and increasing 'farm income' (H2b)) and two subconstructs to describe external benefits ('perceived relationship with buyers' (H2c) and 'perceived usefulness for market access' (H2d)). Thus, we hope to identify positive impacts of these subconstructs on the 'perceived usefulness' of organic certification.

The 'perceived costs' construct is defined as the effort necessary to comply with formal requirements for certification as perceived by a company. This includes managerial and bureaucratic costs such as those for documentation, process modification and organizational adaptation. Agribusiness companies generally indicate that the costs are low or at least moderate. However, Gawron and Theuvsen (2006) report different perceptions of certification costs. In line with these results we suggest that the perceived costs of certification negatively influence the overall evaluation $\left(\mathrm{H}_{3} \mathrm{a}\right)$ as well as the perceived usefulness of organic certification $\left(\mathrm{H}_{3} \mathrm{~b}\right)$. In addition, we introduce two subconstructs as determinants of the 'perceived costs of certification': 'perceived managerial costs' (H4a) and 'perceived bureaucratic costs' (H4b). Since the cost deviations occur due to the 'size of the farm' (Böcker et al., 2003), we proposed this variable as another influencing factor. While it is hypothesized that both subconstructs positively influence the perceived costs, the farm size $\left(\mathrm{H}_{4} \mathrm{C}\right)$ is assessed to have a negative impact.

The next aspect considered is the variable 'years of experience' with organic agriculture. We hypothesize that years of experience possess a positive influence on the evaluation, since adjustments due to the certification criteria can be handled much more easily if a farmer has been working in the organic sector for longer $\left(\mathrm{H}_{5}\right)$.

Generally, intrinsic motivation as shown in the theory of motivational crowding effects (Frey and Jegen, 200I) may increase the willingness of organic farmers to accept a certification system. Farmers who are ideologically motivated should be more willing to accept the burdens of the control system. Organic motivation refers to the fundamental motives of farmers to manage their farms organically. We therefore introduce the motivational construct 'organic motivation' to positively impact the overall evaluation (H6). 
The 'perceived reliability' of the organic certification system refers to the performance of the organic standard. We define this construct as the degree to which a respondent believes that the system is reliable enough to detect noncompliance with regulations. Beyond single case studies and rumours, statistical analyses underline the threat of weak auditing procedures in the agribusiness sector (Albersmeier et al., 2009). Hence, we hypothesize that the higher the satisfaction of organic certification, the greater the perceived reliability $\left(\mathrm{H}_{7}\right)$.

In general, risk is defined as the degree to which a person expresses fears about the uncertainty of something (Bruner et al., 2005). We defined the 'risk perception' construct as the farmer's general perception of fraud practices in organic certification. Since opportunism in organic labelling is reported (Giannakas, 200I), we expected that farmers who were afraid of mislabelling would critically review its reliability (H8).

The 'risk propensity' is conceptualized as the degree to which a person expresses a desire to avoid taking risks (Bruner et al., 2005). Farming is an activity that involves many risks. Organic farming in particular relies on natural resources and excludes conventional management tools through restrictions on the use of chemicals, synthetic medicines, non-farm feeding stuffs and the like (Hanson et al., 2004). Hence, it can be expected that organic farmers are risk averse (Flaten et al., 2004) and consequently stick to the guidelines. Thus, it can be concluded that farmers who perceive organic certification to be reliable show a lower risk propensity (H9).

According to Jahn et al. (2005), for the reliability of third-party certification, the objectivity, experience and independence of the executive certification bodies (CBs) - and the auditors respectively - are critical. Terziovski et al. (2003) assume that the reliability depends on aspects such as the style of the auditor. This impacts appraisal of the certification, because there is evidence that some auditors have no experience with their client's industry or its procedures and products/services. These practices result in poor audit quality and have a negative influence on the certification system. In order to analyse how farmers perceive these institutions and their inspectors, we introduced the construct 'perceived reputation of the CB'. We hypothesize that a good reputation has a positive impact on the overall evaluation (Hıоa) as well as on the perceived reliability of organic certification (Hıob).

Control refers to the possibility that other entities will alert the respective authorities about improper actions carried out by the farmer (van Elzakker et al., 2005). Hence, in accordance with Getz and Shreck (2006), we defined the four constructs 'perceived government pressure' (Hıг), 'perceived association pressure' (Hı2), 'perceived buyer pressure' (Hi3) and 'perceived family pressure' (Hi4) to positively influence the farmers' motivation to stay reliable within the guidelines of the organic standard. While government and buyer pressure refer to external forces, we presume that internal parties - such as the farmers' association and even their families - also influence reliable implementation by means of a social monitoring system. Association and family have an interest in a functioning system since both will suffer from economic and social losses in cases of fraud.

\section{Data Collection}

Between November 2007 and January 2008, I49 organic farmers were surveyed. Since most of the farmers are isolated and broadly dispersed, the study was conducted via either personal interviews (75), personally guided telephone (I4) or email surveys (60). In Costa Rica 62 organic growers out of a total of 3987 farmers completed the questionnaire, and in Brazil 87 of around 14000 farmers participated. Thus, the study is a 'convenience sample' (Lunneborg, 2007) and does not fulfil the criteria of representativeness; nevertheless, the sample allows for differentiated statistical analysis.

The survey contains answers from farmers working with the main organic commodities produced in the countries and affiliated with the main certification bodies. The questionnaire was completed primarily by farm owners $(66.9 \%)$ and managers/administrators (12.2\%). 51.7\% of the organic growers went to primary or secondary school, while $30.9 \%$ hold bachelor degrees. On average the respondents were 42.9 years old and had practised organic farming for ten years. The farms within our sample are around ig8 hectares (885), ${ }^{\mathrm{I}}$ and the number of employees averages 34 persons (25I). The large standard deviations indicate the difference between small family farms and some big farms, concentrated on export. The sample from Brazil contains larger farms, and the sample from Costa Rica has more experienced owners/managers. Separate statistics for the two countries are presented in Table I. All

${ }^{\mathrm{I}}$ (standard deviation). 


\begin{tabular}{|c|c|c|c|c|c|}
\hline & Age & $\begin{array}{c}\text { Gender - } \\
\text { female/male }\end{array}$ & $\begin{array}{l}\text { Experience with } \\
\text { organic farming }\end{array}$ & Size of farm & $\begin{array}{c}\text { Number of } \\
\text { workers/employees }\end{array}$ \\
\hline
\end{tabular}

Table 1. Description of the samples from Brazil and Costa Rica (standard deviation)

Source: authors' calculations.

in all, the respondents from both countries seem to be able to evaluate the strengths and weaknesses of organic certification.

\section{Measures and Statistical Approach}

Items used in the questionnaire were adopted and developed from previous studies dealing with farmers' acceptance and their evaluation of different QASs in European agribusiness (Jahn and Spiller, 2005; Schulze et al., 2007). The respective items were primarily evolved from constructs identified in literature dealing with behavioural research, cost-benefit analyses and especially the technology acceptance model (TAM) developed by Davis (I989). Furthermore, the basic model refers to the theory of bureaucracy (Weber, I968).

To capture the latent variables of the research model, we used Likert scales and semantic differential items $(-3$ to +3$)$. All of them were examined beforehand using factor analysis. After minor modifications for double loading and nonloading, item measurements demonstrated acceptable levels of fit and reliability.

Causal models with latent constructs can be defined by covariance-based structural equation modelling or the partial least squares (PLS) method. The data analysis of this contribution is achieved by PLS, a componentbased structural equation modelling technique. PLS is a combination of path, principal component and regression analyses. It examines the relationships among the latent constructs within the research model in a single operation.

PLS has many advantages that make this technique particularly suitable for this study. It is especially effective for model testing and exploratory studies. PLS is adopted because it is appropriate for very complex structural models and has minimal requirements as to residual distributions and sample size (Chin, I998a, I998b; Gefen et al., 2000). Other statistical programs, such as LISREL, require a sample size of 200 and above.

PLS entails a two-stage approach. First, the measurement model is evaluated in order to assess the reliability and validity of the measurement instruments. Afterwards, the structural model of the relationships between the constructs is tested. The statistical program used for the analyses is SmartPLS version 2.0.M3. ${ }^{2}$

\section{Data Analysis and Results}

\section{Testing the Measurement Model}

The measurement model consists of the relationships between the constructs (see Figure I) and the observed items (see the appendix) applied to measure them. The suitability of the measurement model is evaluated by examining individual item reliabilities and internal consistency as well as by assessing the discriminant validity of the measurements.

Individual item reliabilities are evaluated by examining the factor loadings of the items on their respective constructs (see the appendix). Items with factor loadings of at least 0.5 are generally considered significant (Hair et al., I998). All items demonstrate a good level of reliability with loadings higher than 0.5 .

\footnotetext{
${ }^{2}$ Developed by the Institute of Operations Management and Organization of the University of Hamburg (Germany) (Ringle et al., 2005).
} 


\begin{tabular}{|c|c|c|c|c|c|}
\hline Code & Item & $\mathrm{NOI}$ & CRA & CR & AVE \\
\hline AP & association pressure & 3 & 0.68 & 0.81 & 0.60 \\
\hline$B C$ & bureaucratic costs & 3 & 0.78 & 0.87 & 0.69 \\
\hline $\mathrm{BP}$ & buyer pressure & 2 & 0.57 & 0.82 & 0.70 \\
\hline $\mathrm{FI}$ & farm income & 2 & 0.53 & 0.79 & 0.66 \\
\hline FP & family pressure & 2 & 0.67 & 0.81 & 0.69 \\
\hline GP & government pressure & 1 & 1.00 & 1.00 & 1.00 \\
\hline $\mathrm{HA}$ & size of farm (ha) & 1 & 1.00 & 1.00 & 1.00 \\
\hline MA & market access & 2 & 0.50 & 0.74 & 0.61 \\
\hline $\mathrm{MC}$ & managerial costs & 2 & 0.34 & 0.75 & 0.60 \\
\hline OB & operational benefits & 3 & 0.58 & 0.78 & 0.54 \\
\hline $\mathrm{OE}$ & overall evaluation & 1 & 1.00 & 1.00 & 1.00 \\
\hline OM & organic motivation & 2 & 0.50 & 0.80 & 0.66 \\
\hline PC & perceived costs & 2 & 0.61 & 0.84 & 0.72 \\
\hline PU & perceived usefulness & 2 & 0.78 & 0.90 & 0.82 \\
\hline RB & relationship with buyers & 2 & 0.39 & 0.76 & 0.62 \\
\hline $\mathrm{RCB}$ & reputation of the $C B$ & 4 & 0.67 & 0.80 & 0.51 \\
\hline RE & perceived reliability & 4 & 0.69 & 0.81 & 0.52 \\
\hline RPE & risk perception & 1 & 1.00 & 1.00 & 1.00 \\
\hline RPR & risk propensity & 2 & 0.35 & 0.75 & 0.60 \\
\hline YE & years of experience & 1 & 1.00 & 1.00 & 1.00 \\
\hline \multicolumn{6}{|c|}{$\begin{array}{l}\mathrm{NOI}=\text { Number of items; CRA = Cronbach's Alpha; CR = Composite Reliability; } \\
\text { AVE = Average variance extracted from the contracts }\end{array}$} \\
\hline
\end{tabular}

Table 2. Assessment of the measurement model

Source: authors' calculations.

The internal consistency of the various constructs is observed by calculating the composite reliabilities (CRs). In this study, the CR of every construct in the final measurement model was greater than 0.7 (see Table 2), which is the suggested value for measures to be considered reliable (Fornell and Larcker, I98I) (similar to Cronbach's alpha: Nunnally, I978).

Another indicator of internal consistency is Cronbach's alpha (CRA). CRA should be 0.6 or higher in order to reveal the reliability of constructs. Not all constructs in the presented model show an $\alpha$ higher than 0.6 (see Table 2). Eight out of the 23 constructs display only low reliability scores. This might indicate a problem with internal consistency, but, on the other hand, the individual-item reliabilities and CR are indicative of acceptable convergent validity. Furthermore, the quality of the CRA greatly depends on the number of items in a construct. Against this background, the presented values are tolerable since they are based on a limited number of indicators. According to measurement theory (Fornell and Larcker, I98I), this is altogether an acceptable statistical solution for internal consistency.

The average variance extracted (AVE) is the average variance shared between a construct and its items. Chin (I998a) suggested an AVE higher than 0.5, meaning that convergent valid measures contain less than 50\% error variance. This holds true for all constructs in the model. Satisfactory values can also be found for discriminant validity, which exists when the shared variance among any two constructs is less than the squared AVE of each construct (Fornell and Larcker, I98I).

\section{Results of the Hypothesized Structural Model}

The structural model was tested to evaluate the hypothesized relationships in the proposed research model (see Figure I). The $R^{2}$ (explained variance) and the sign and significance of path coefficients were applied to assess the structural model. 
In the structural model, each path characterizes one hypothesis. Path coefficients are analogous to the standardized beta weights in regression analysis. The corresponding $t$-values are assessed using the jackknife method. Good structural model fit exists when there are a sufficiently high explanatory relative power $\left(R^{2}\right)$ and statistically significant $t$-values. A bootstrapping method with rooo samples was applied to evaluate the significance of the path estimates. Figure 2 presents the results of the hypothesized structural model.

The $R^{2}$ for each of the endogenous variables was as follows: overall evaluation 0.40 , perceived reliability 0.53 , perceived usefulness 0.57 and perceived bureaucratic costs 0.40 . Taking into account the complexity of the research model, this result is satisfactory.

The majority of the suggested factors have an impact on the overall evaluation. The most important effect, that of perceived usefulness on the overall evaluation, is $0.35^{* * *}(\mathrm{HI})$. The CB's reputation (0.28***), perceived costs $\left(-0.25^{* * *}\right)$ and years of experience (-0.1 $\left.4^{* *}\right)$ are further decisive constructs. Together, these constructs explain $40 \%$ of the variance in the overall evaluation of the organic certification system. In contrast, the organic motivation of the farmer does not have a significant effect.

The most important determinants of perceived reliability are the reputation of the CB $(0.30 * * *)$, the pressure of the farmer's association (0.29***) and the overall evaluation of the system (0.I7*). Moreover, the construct is influenced by risk propensity (-O.I4**) as well as buyer pressure (-0.12**). The results indicate that government and family pressure as well as risk perception do not have a significant influence on reliability. While hypotheses $\mathrm{H}_{7}, \mathrm{H}_{9}$, Hiob, Hi2 and Hi3 can be accepted, hypotheses H8, His and Hi4 must be rejected. The $R^{2}$ for the perceived reliability construct is 0.53 .

The perceived usefulness construct is an endogenous variable of multiple subconstructs. The results show that operational benefits $\left(0.67^{* * *}\right)$ and relationship with buyers $(0.20 * *)$ have a strong significant effect on perceived usefulness. Because farm income, market access and perceived costs have no significant effect, hypotheses $\mathrm{H} 2 \mathrm{~b}$, $\mathrm{H}_{2} \mathrm{~d}$ and $\mathrm{H}_{3} \mathrm{~b}$ must be rejected. All in all, $57 \%$ of the perceived usefulness variance could be explained. Regarding

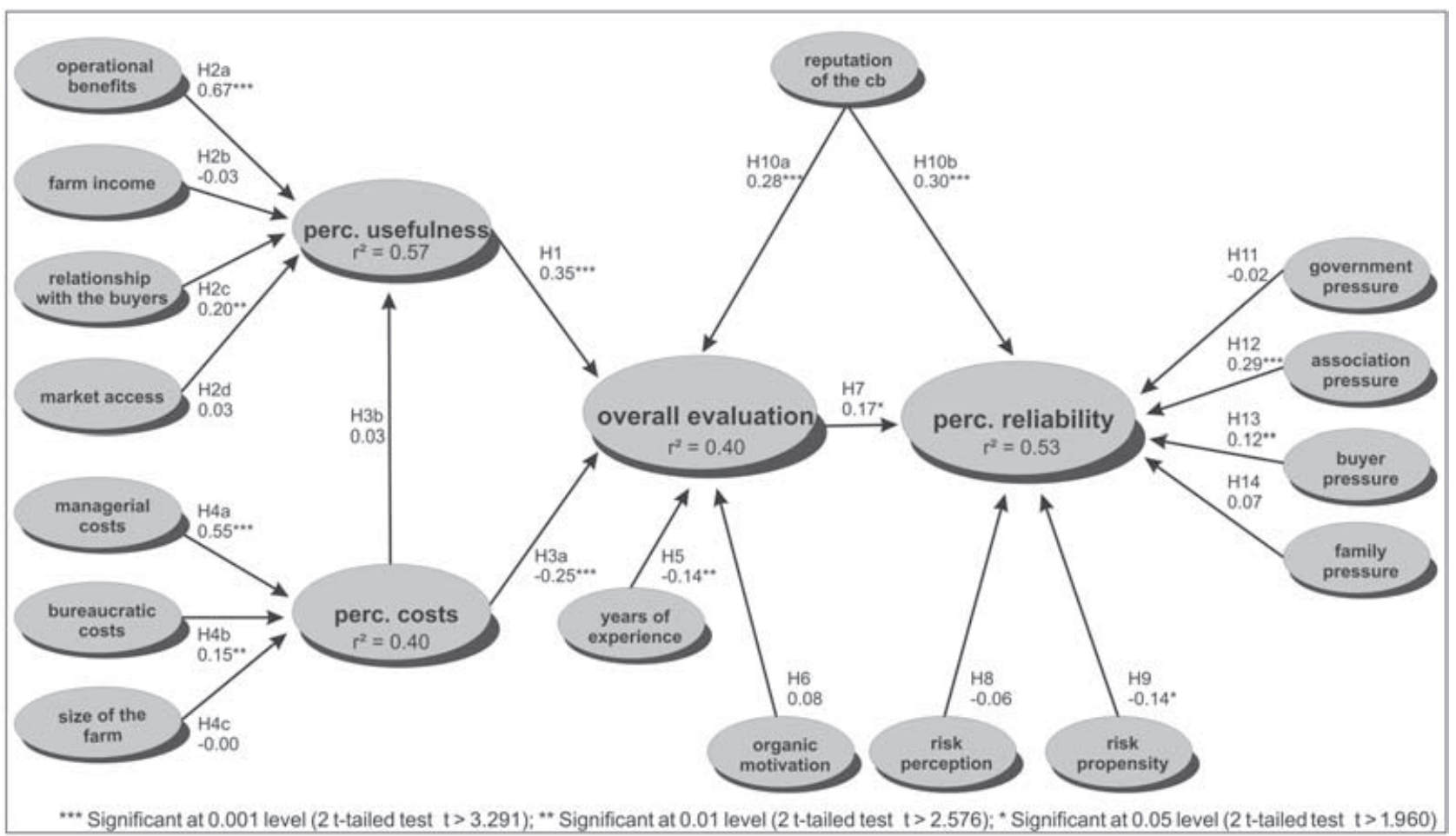

Figure 2. Structural model 
the perceived cost construct, no effect can be verified for farm size. $\mathrm{H}_{4} \mathrm{c}$ must, therefore, be rejected, whereas $\mathrm{H}_{4} \mathrm{a}$ and $\mathrm{H}_{4} \mathrm{~b}$ are confirmed. All in all, $40 \%$ of the variance was discovered.

Interpretation of these findings can be drawn only very carefully due to the explorative character of this study. However, initial results show that the overall evaluation of organic certification is more favourable if farmers experience an increase in operational benefits (such as better quality management) and a better relationship with buyers (perceived usefulness). Increasing farm income and better market access play only minor roles. These may be due to the fact that the system is only semi-optional - if farmers want to export, they need to have the certificate. The perceived costs lower the overall evaluation with organic certification. Furthermore, satisfaction with the system, which is measured by the overall evaluation construct, has a significant effect on the perception of the system's reliability. Finally, association pressure and especially the reputation of the CB are important determinants for the reliability of organic certification. The latter result highlights the relevance of professional CBs and highperforming auditors.

\section{Conclusion}

Initial studies in the agribusiness sector have uncovered two main problems concerning the implementation of a QAS: (I) the cost-benefit ratio is often negatively evaluated, and (2) communication, which is necessary for successful implementation, is neglected. As a consequence, a gap of acceptance has been revealed in the literature (Jahn and Spiller, 2005). However, endorsement is essential for a certification system that aims to be reliable.

The results of this study indicate that acceptance (overall evaluation) of the organic scheme is higher and less controversial in Latin America than in Europe. Furthermore, the influence of the acceptance of the organic certification system on the perceived reliability is proved for the first time. Hence, an increase in farmers' conviction is the basic step in ensuring farmers' diligence in the organic certification standard. Such changes should be accompanied by proper communication of costs but especially benefits. In particular, higher operational benefits, a better relationship with buyers and lower managerial and bureaucratic costs are key factors in reaching this aim.

Another aspect that emphasizes the need for a reliable organic certification system (Walgenbach, 2007) is risk perception regarding fraud practices in the production sector. Although this factor has no significant influence on the perceived reliability of the certification system (H8), practice, other studies (Jahn et al., 2005; Albersmeier et al., 2009) and the descriptive analysis indicate that fraud is still an important issue. For example, 41.6\% of farmers believe that the number of 'black sheep' in the organic farming sector will rise, and $20.8 \%$ partly agree with this perception (see the appendix). It seems that most respondents are very aware that cheating generally occurs. However, they are still unaware of the consequences (for export) connected with fraud. Personal interviews with representatives of public authorities and certification bodies in both countries revealed, that the fraud discussion is limited to developed countries (e.g. Europe and the US).

Our results demonstrate that beside the perceived usefulness of the certification system the reputation of the $\mathrm{CB}$, which includes the skills and thoroughness of their auditors, is a major factor for enhancement of the perceptions of the system's reliability. However, the results of statistical analyses of other QASs in the food business reveal highly significant deviations between the auditing judgements of the various certification bodies and auditors (see Albersmeier et al., 2009). These findings indicate variations in the level of audit quality or thoroughness. Therefore, better training and further education of auditors, as well as the development of an audit quality control system, seem necessary to prevent the threat of weak auditing procedures in organic certification and a loss of reliability.

All in all, increasing the efficiency and effectiveness of the control procedure is important, as is decreasing costs (bureaucracy). Therefore, the relationship between product and process management should be linked more closely in order to prevent pure 'give-me-paper' procedures and to increase the effectiveness of the inspection. For this purpose, laboratory analyses of organic quality and management metasystems can be combined. Improved checklists and well educated auditors are further means of reaching this objective.

Besides internal improvements of the system's effectiveness, external variables can enforce the reliability of the certification scheme. The results show that buyers and farmers' associations in particular can perform a social 
monitoring function. At the same time, it becomes obvious that governments in Latin America possess a rather weak position in this discussion. This may be due to the rather low influence of public authorities on the organic (export) sector. Hence, the results imply that more emphasis has to be placed on the function of private institutions as control bodies. Thus, these findings provide further arguments for the current discussion on the potential for industrial self-regulation versus public command-and-control systems.

Due to the explorative character of the study, some questions remain unanswered. The reduced size of our samples further limits the conclusions that can be drawn from them. Moreover, the results are not easily transferable to other Latin American countries. To reach further insights, a wider sample and detailed (quantitative and qualitative) analyses are required. Conceptually, the study is restricted by its exclusive focus on the perceptions of farmers. However, the farmer's evaluation of the system is only one indicator of its reliability; another important variable is consumer/customer acceptance and trust in the scheme. Thus, further research along the whole organic supply chain is needed in order to gain a broader picture of the attitudes of various stakeholders (e.g. exporter/ importer, consumers) concerning the reliability of the organic certification system (Adams and Ghaly, 2007). In addition, the reputation of the CBs has to be further analysed.

\section{References}

Adams MAG, Ghaly AE. 2007. Determining barriers to sustainability within the Costa Rican coffee industry. Sustainable Development I5(4): 229-24I.

Albersmeier F, Schulze H, Jahn G, Spiller A. 2009. The reliability of third-party certification in the food chain: from checklists to risk oriented auditing. Food Control 20(I0): 927-935.

Amstel MV, Driessen P, Glasbergen P. 2007. Eco-labeling and information asymmetry: a comparison of five eco-labels in the Netherlands. Journal of Cleaner Production I6(3): 263-276.

Anania G, Nisticò R. 2004. Public regulation as a substitute for trust in quality food markets. What if trust substitute cannot be fully trusted? Journal of Institutional and Theoretical Economics I60: 68I-70I.

Anders S, Souza Monteiro DM, Rouviere E. 2007. Objectiveness in the market for third-party certification: what can we learn from market structure? The I05th EAAE-Seminar, Bologna, 2007.

Barrett HR, Browne AW, Harris PJC, Cadoret K. 2002. Organic certification and the UK market: organic imports from developing countries. Food Policy 27(4): 30I-3I8.

Batte MT, Hooker NH, Haab C. 2007. Putting their money where their mouths are: consumer willingness to pay for multi-ingredient, processed organic food products. Food Policy 32: I45-I59.

Beske P, Koplin J, Seuring S. 2008. The use of environmental and social standards by German first-tier suppliers of the Volkswagen AG. Corporate Social Responsibility and Environmental Management 15(2): 63-75.

Böcker A, Bredahl ME, Northen J. 2003. ISO 9000 certification in British agribusiness: motivations and performance impacts. In Proceedings of the 82nd EAAE Seminar, Schiefer G, Rickert U (eds). University of Bonn: Bonn; 5I-6o.

Bonapace T. 200I. Organic agriculture: environmental issues and ESCAP countries. In Enhancing Export Opportunities Through Environmentally Sound Business Development, Studies in Trade and Environment No. 44. Trade and Investment Division (TID); 8I-IO6.

Botanaki A, Polymeros K, Tsakiridou E, Mattas K. 2005. The role of food quality certification on consumers' food choices. British Food Journal Iо8(2): 77-90.

Bruner P, Hensel P, James K. 2005. Marketing Scales Handbook Volume IV: a Compilation of Multi-Item Measures for Consumer Behavior and Advertising. Thomson: Chicago, $\mathrm{OH}$.

Caswell JA, Bredahl ME, Hooker NM. I998. How quality management systems are affecting the food industry. Review of Agricultural Economics 20(2): 547-557.

Chin WW. I998a. Issues and opinion on structural equation modeling. MIS Quarterly 22(I): vii-xvi.

Chin WW. I998b. The partial least squares approach to structural equation modeling. In Modern Methods for Business Research, Marcoulides GA (ed.). Erlbaum: Hillsdale, NJ; 295-336.

Davis FD. I989. Perceived usefulness, perceived ease of use, and user acceptance of Information Technology. MIS Quarterly I3(3): 3I9-340.

Fitzgerald AI, Storer CE, Bent MJM. I999. Impediments to adoption of on-farm quality assurance. The I2th International Farm Management Congress, Durban, I999.

Flaten O, Lien G, Koesling, M, Valle P, Ebbesvik M. 2004. Comparing Risk Perceptions and Risk Management in Organic and Conventional Dairy Farming. The 86th EAAE Seminar, Anacapri, 2004.

Fornell C, Larcker DF. I98I. Evaluating structural equations models with unobservable variables and measurement error. Journal of Marketing Research $\mathrm{I} 8(\mathrm{I}): 39-50$.

Fouayzi H, Caswell JA, Hooker N. 2006. Motivations of fresh-cut produce firms to implement quality management systems. Review of Agricultural Economics 28(I): 132-I46.

Frey BS, Jegen R. 200I. Motivation crowding theory. Journal of Economic Surveys I5(5): 589-6II. 
Gawron J-C, Theuvsen L. 2006. The International Food Standard: Bureaucratic Burden or Helpful Management Instrument in Global Markets? The 98th EAAE Seminar, Chania, 2006.

Gefen D, Straub DW, Boudreau M. 2000. Structural equation modeling and regression: guidelines for research practice. Communications of the Association for Information Systems 4(7): I-70.

Getz C, Shreck A. 2006. What organic and Fair Trade labels do not tell us: towards a place-based understanding of certification. International Journal of Consumer Studies 30(5): 490-50I.

Giannakas K. 200I. Information asymmetries and consumption decisions in organic food product markets. Canadian Journal of Agricultural Economics 50(I): 35-50.

Hair FJ, Anderson ER, Ronald LT, Black CW. I998. Multivariate Data Analysis. Prentice-Hall: Englewood Cliffs, NJ.

Hanson J, Dismukes R, Chambers W, Greene C, Kremen A. 2004. Risk and risk management in organic agriculture: views of organic farmers. Renewable Agriculture and Food Systems I9(4): 2I8-227.

Hunt HK. I977. CS/D - overview and future directions. In Conceptualization and Measurement of Consumer Satisfaction and Dissatisfaction. Marketing Science Institute: Cambridge; 7-23.

Jahn G, Schramm M, Spiller A. 2005. The reliability of certification: quality labels as a consumer policy tool. Journal of Consumer Policy 28(I): $53-73$.

Jahn G, Spiller A. 2005. Acceptance of a Processor-Driven Quality Management System by Dairy Farmers: a Structural Equation Model. The 92nd EAAE Seminar, Göttingen, 2005.

Jatib I. 2003. Food safety and quality assurance key drivers of competitiveness. International Food and Agribusiness Management Review 6(I): $38-56$.

Kilcher L. 2007. How organic agriculture contributes to sustainable development. Journal of Agriculture and Rural Development in the Tropics and Subtropics 89(supplement): 3I-49.

Kleinwechter U, Grethe H. 2006. The adoption of the Eurepgap standard by mango exporters in Piura, Peru. The 26th IAAE Conference, Brisbane, 2006.

Lunneborg CE. 2007. Convenience sample. In Blackwell Encyclopedia of Sociology, Ritzer G (ed.). Blackwell Publishing, Blackwell Reference Online. http://www.blackwellreference.com/public/tocnode?id=g978I405I2433I_chunk_g978I405I2433I9_ssl-I32 [I4 July 2009].

Maes A, Poels G, Gailly F, Paemeleire R. 2005. Measuring User Beliefs and Attitudes Towards Conceptual Models: a Factor and Structural Equation Model, Working Paper 2005/3II.

Martinez MG, Bañados F. 2004. Impact of EU organic product certification legislation on Chile organic exports. Food Policy 29(I): II4.

McCluskey JJ. 2000. A game theoretic approach to organic foods: an analysis of asymmetric information and policy. Agricultural and Resource Economics Review 29(I): I-9.

Meuwissen M, Velthuis A, Hogeveen H, Huirne R. 2003. Traceability and certification in meat supply chains. Journal of Agribusiness 2I: I67-I8I.

Neuendorff J, Fischer U. 2007. Maintaining organic integrity: tackling fraud in organics. In Quality Management in Food Chains, Theuvsen L, Spiller A, Peupert M, Jahn G (eds). Academic: Wageningen; 209-2I7.

Nunnally J. 1978. Psychometric Theory. McGraw-Hill: New York.

Pawłowski A. 2008. How many dimensions does sustainable development have? Sustainable Development I6(2): 8I-90.

Ringle CM, Wende S, Will S. 2005. SmartPLS 2.0 (M3) Beta. http://www.smartpls.de [I2 June 2008].

Rust RT, Oliver RT. I994. Service quality: Insights and managerial implications from the frontier. In Service Quality: New Directions in Theory and Practice, Rust RT, Oliver RT (eds). Sage: New York; I-2O.

Schulze H, Albersmeier F, Gawron J-C, Spiller A, Theuvsen L. 2008. Heterogeneity in the evaluation of quality assurance systems: the International Food Standard (IFS) in European agribusiness. International Food and Agribusiness Management Review II(3): 99I38.

Schulze H, Jahn G, Spiller A. 2007. Acceptance of the organic certification system by farmers in Germany. The I7th IAMA World Forum and Symposium Conference, Parma, 2007.

Singels J, Ruel G, Van der Water H. 200I. ISO 900I series: certification and performance. International Journal of Quality and Reliability Management I8(I): 62-75.

Terziovski M, Power D, Sohal AS. 2003. The longitudinal effects of the ISO 900I certification process on business performance. European Journal of Operational Research I46(3): 580-595.

Theuvsen L, Spiller A. 2007. Perspectives of quality management in modern agribusiness. In Quality Management in Food Chains, Theuvsen L, Spiller A, Peupert M, Jahn G (eds). Academic: Wageningen; I3-I9.

van Elzakker B, Neuendorff J, Torjusen H, O’Doherty K, Brandt K. 2005. Autenticidad y Fraude: Información Destinada a los Vendedores Sobre el Control de la Calidad y Seguridad Alimenticia en las Cadenas de Producción Orgánica, informative booklet. Research Institute of Organic Agriculture FiBL: Frick, Switzerland.

Vermeulen WJV. 2008. Sustainable global product chains: actors, systems and mechanisms at three levels. The I4th Annual International Sustainable Development Research Conference, New Delhi, 2008.

Vermeulen WJV, Ras PJ. 2006. The challenge of greening global product chains: meeting both ends. Sustainable Development I4(4): 245256.

Walgenbach P. 2007. Façade and means of control: the use of ISO 9000 standards. In Quality Management in Food Chains, Theuvsen L, Spiller A, Peupert M, Jahn G (eds). Academic: Wageningen; 29-42.

Weber M. I968. Economy and Society. Bedminster: New York. 
Willer H, Yussefi M. 2006. The World of Organic Agriculture. Statistics and Emerging Trends 2006. IFOAM-FiBL: Bonn.

Yussefi M. 2006. Organic agriculture worldwide 2006. Overview and main statistics. In The World of Organic Agriculture. Statistics and Emerging Trends 2006, Willer H, Yussefi M (eds). IFOAM-FiBL: Bonn; 23-37.

\section{Appendix}

\begin{tabular}{|c|c|c|c|c|}
\hline & Statements & $\varnothing$ & $\sigma$ & $\mathrm{r}$ \\
\hline OE & I am satisfied with the organic certification. & 1.79 & 1.12 & 1.00 \\
\hline RE1 & Cheaters are discovered during the inspection. & 1.23 & 1.70 & 0.71 \\
\hline RE2 & Violations against the guidelines are rarely discovered. & -1.16 & 1.61 & 0.50 \\
\hline RE3 & The certification process is reliable. & 1.88 & 1.04 & 0.86 \\
\hline $\mathrm{RE}_{4}$ & Inspectors notice if other farmers sometimes do not follow the guidelines. & 1.73 & 1.04 & 0.78 \\
\hline PU1 & The organic certification standard is very useful. & 1.91 & 0.93 & 0.89 \\
\hline $\mathrm{PU}_{2}$ & Organic certification standards enhance the effectiveness of my organic practices. & 1.37 & 1.58 & 0.92 \\
\hline $\mathrm{OB}_{1}$ & The author gives me good ideas to improve the management of my farm. & 0.65 & 1.92 & 0.65 \\
\hline OB2 & I do better quality management since receiving organic certification. & 1.30 & 1.53 & 0.75 \\
\hline $\mathrm{OB}_{3}$ & Our course of business has become clearer through the certification process. & 1.73 & 1.29 & 0.81 \\
\hline $\mathrm{Fl}_{1}$ & My income has increased since receiving organic certification. & 0.81 & 1.67 & 0.94 \\
\hline $\mathrm{Fl}_{2}$ & I had more income with conventional agriculture than with organic agriculture. & -0.88 & 1.59 & 0.66 \\
\hline $\mathrm{RB} 1$ & I have a better relationship with my buyers since receiving organic certification. & 1.68 & 1.20 & 0.72 \\
\hline RB2 & Since my farm became organic, my business relations have increased. & 1.43 & 1.41 & 0.85 \\
\hline MA 1 & I need the organic certification to be able to sell my products. & 1.61 & 1.57 & 0.98 \\
\hline MA2 & I acquired the certification only to have market access. & 0.03 & 2.06 & 0.51 \\
\hline $\mathrm{PC}_{1}$ & The costs of organic certification are too high. & 1.22 & 1.59 & 0.89 \\
\hline $\mathrm{PC} 2$ & The costs of certification are higher than the benefits. & -0.46 & 1.89 & 0.81 \\
\hline $\mathrm{MC} 1$ & The fee for the certification process is not so high. & -0.58 & 1.77 & 0.80 \\
\hline $\mathrm{MC} 2$ & The time expenditure required for certification is too great. & -0.19 & 1.95 & 0.75 \\
\hline $\mathrm{BC}_{1}$ & The organic certification control system is very bureaucratic. & 0.93 & 1.69 & 0.91 \\
\hline $\mathrm{BC}_{2}$ & There is too much documentation required for organic certification. & 0.01 & 1.87 & 0.82 \\
\hline $\mathrm{BC}_{3}$ & The bureaucracy needed to obtain certification has increased in recent years. & 1.28 & 1.60 & 0.75 \\
\hline $\mathrm{OM}_{1}$ & If the prices do not improve, I will return to conventional farming. & -1.50 & 1.70 & 0.86 \\
\hline $\mathrm{OM}_{2}$ & I would never farm conventionally. & 1.02 & 1.83 & 0.77 \\
\hline \multicolumn{5}{|c|}{$\begin{array}{l}\text { Scale from }+3=\text { totally agree to }-3=\text { totally disagree; } \varnothing=\text { mean; } \sigma=\text { standard deviation; } r=\text { factor loading; for the item code see } \\
\quad \text { Table } 3\end{array}$} \\
\hline
\end{tabular}

Table A1. Descriptive measurement items

Source: authors' calculations. 


\begin{tabular}{|c|c|c|c|c|}
\hline & Statements & $\varnothing$ & $\sigma$ & r \\
\hline RPE1 & I am worried that the number of black sheep in the organic sector is increasing. & 0.07 & 1.84 & 1.00 \\
\hline RPR1 & I avoid risky situations. & 1.64 & 1.47 & 0.88 \\
\hline RPR2 & Compared to most people I know, I like to take risks. & -0.56 & 2.15 & 0.66 \\
\hline $\mathrm{RCB} 1$ & I chose this CB because it has a good reputation. & 1.54 & 1.27 & 0.55 \\
\hline RCB2 & Our auditor tries to find the weak points on my farm. & 1.81 & 1.09 & 0.65 \\
\hline $\mathrm{RCB}_{3}$ & The work done by the auditors of my CB is very professional. & 2.07 & 0.92 & 0.85 \\
\hline $\mathrm{RCB} 4$ & The performance of the auditor during the inspection is accurate. & 1.85 & 1.16 & 0.77 \\
\hline GP1 & The government punishes farmers who show opportunistic behaviour. & -0.86 & 1.90 & 1.00 \\
\hline $\mathrm{AP} 1$ & $\begin{array}{l}\text { Producers are aware that, if any of them cheat, that could be detrimental to the reputation of } \\
\text { the association. }\end{array}$ & 1.93 & 1.18 & 0.82 \\
\hline $\mathrm{AP}_{2}$ & If my neighbours discovered I had done something wrong, they would denounce me. & 1.35 & 1.50 & 0.81 \\
\hline $\mathrm{AP}_{3}$ & $\begin{array}{l}\text { My organic-certified neighbours monitor my compliance with the requirements of the } \\
\text { certification. }\end{array}$ & 0.71 & 1.81 & 0.68 \\
\hline $\mathrm{BP} 1$ & My buyer checks to see that I keep to the guidelines. & 1.14 & 1.90 & 0.79 \\
\hline $\mathrm{BP} 2$ & My buyer warns me frequently about the consequences of cheating. & 0.34 & 2.01 & 0.88 \\
\hline $\mathrm{FP} 1$ & My family cares whether I fulfil the requirements of organic farming. & 1.42 & 1.66 & 0.99 \\
\hline $\mathrm{FP} 2$ & My family has no interest in my organic business. & -1.59 & 1.63 & 0.64 \\
\hline YE & For how many years have you practiced organic agriculture? & 1009 & 6.70 & 1.00 \\
\hline
\end{tabular}

Table A2. Descriptive measurement items

Source: authors' calculations. 